\title{
OPEN Isolation and characterization of a halophilic Modicisalibacter sp. strain Wilcox from produced water
}

\author{
William S. Marsh ${ }^{1}$, Brenden W. Heise ${ }^{1}$, Mark J. Krzmarzick ${ }^{2}$, Robert W. Murdoch ${ }^{3,4}$ \& \\ Babu Z. Fathepure ${ }^{1 凶}$
}

We report the isolation a halophilic bacterium that degrades both aromatic and aliphatic hydrocarbons as the sole sources of carbon at high salinity from produced water. Phylogenetic analysis of 16S rRNAgene sequences shows the isolate is a close relative of Modicisalibacter tunisiensis isolated from an oilfield water in Tunisia. We designate our isolate as Modicisalibacter sp. strain Wilcox. Genome analysis of strain Wilcox revealed the presence of a repertoire of genes involved in the metabolism of aliphatic and aromatic hydrocarbons. Laboratory culture studies corroborated the predicted hydrocarbon degradation potential. The strain degraded benzene, toluene, ethylbenzene, and xylenes at salinities ranging from 0.016 to $4.0 \mathrm{M} \mathrm{NaCl}$, with optimal degradation at $1 \mathrm{M} \mathrm{NaCl}$. Also, the strain degraded phenol, benzoate, biphenyl and phenylacetate as the sole sources of carbon at $2.5 \mathrm{M} \mathrm{NaCl}$. Among aliphatic compounds, the strain degraded $n$-decane and $n$-hexadecane as the sole sources of carbon at $2.5 \mathrm{M} \mathrm{NaCl}$. Genome analysis also predicted the presence of many heavy metal resistance genes including genes for metal efflux pumps, transport proteins, and enzymatic detoxification. Overall, due to its ability to degrade many hydrocarbons and withstand high salt and heavy metals, strain Wilcox may prove useful for remediation of produced waters.

The inevitable contamination of soil and water by hydrocarbons and brine during oil and gas exploration, production and transportation operations results in potentially harmful impacts on human health and the environment ${ }^{1}$. For example, contamination of soil with saline wastewater (commonly called produced water (PW)) generated during oil and natural gas extraction can seriously damage soil properties, lead to soil erosion, cause the death of vegetation, and contaminate both surface and ground water ${ }^{1,2}$. Physicochemical treatment methods for the removal of hydrocarbons from PW are expensive and impractical. Hence, it is necessary to explore biological strategies for the remediation of PW. There have been numerous studies on the biodegradation of petroleum compounds in non-saline or low salinity conditions. Many microorganisms belonging to diverse genera have been isolated and their physiology, ecology, and genomics have been well characterized. In some instances, their practical applications have been realized ${ }^{3-10}$. However, relatively little is known about the microbial degradation of hydrocarbons in hypersaline environments such as PW, especially about their practical application for bioremediation. This is paramount, as conventional microorganisms cannot function well in high-salinity conditions due to disruption of the cell membrane, denaturation of proteins, and other detrimental effects.

Interest in the treatment of PW has significantly increased in recent years, as this is one of the oil-industry's largest waste products generated; about 21 billion barrels of PW per year in the United States alone ${ }^{11}$. If properly treated, this water could be reused in agriculture or industry, especially considering recent droughts and water shortages in much of the south-central and western United States. Most PWs are highly saline, sometimes reaching $>30 \%(\mathrm{w} / \mathrm{v})$ salinity (here and throughout the manuscript, we define salinity as the concentration of $\mathrm{NaCl}$ ) and contain a variety of aromatic, alicyclic, and aliphatic hydrocarbons and other organics. In addition, a slew of heavy metals $(\mathrm{Pb}, \mathrm{Mg}, \mathrm{Zn}, \mathrm{Cu}, \mathrm{Fe}, \mathrm{B}$, and others) and naturally occurring radionuclides are often present in most $\mathrm{PW}^{11}$. These vast volumes of $\mathrm{PW}$ with unknown chemistries pose serious water management challenges and remediation is costly. To date, most oil and gas production operations dispose their PW via deep-well injection in Class II disposal wells ${ }^{11,12}$. However, such disposal practices have the potential to contaminate the subsurface and cause other environmental damage, including earthquakes ${ }^{13,14}$. Therefore, developing a cost-effective and

${ }^{1}$ Department of Microbiology and Molecular Genetics, Oklahoma State University, Stillwater, OK 74078, USA. ${ }^{2}$ Civil and Environmental Engineering, Oklahoma State University, Stillwater, OK 74078, USA. ${ }^{3}$ Center for

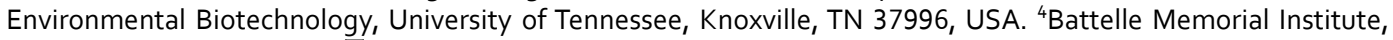
Columbus, OH 43201, USA. ${ }^{\circledR}$ email: babu.fathepure@okstate.edu 


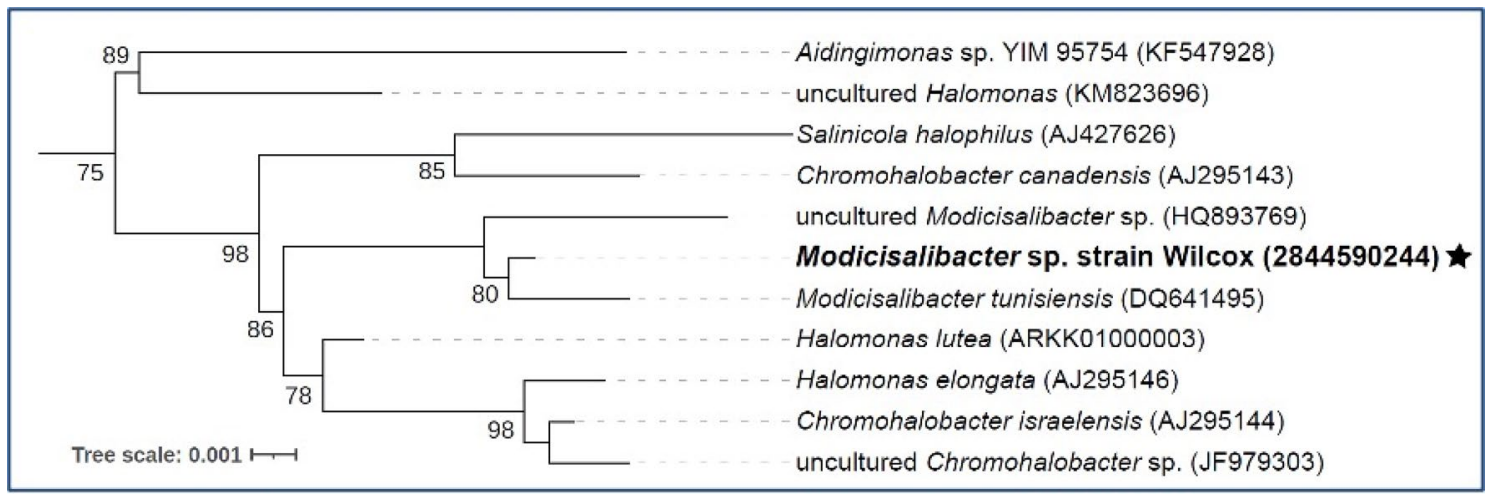

Figure 1. FastTree maximum likelihood approximation phylogenetic tree of $16 \mathrm{~S}$ rRNA gene sequences of Wilcox and its most closely related phylogenetic neighbors. Only bootstrap values above $75 \%$ are shown. Integrated Microbial Genomes (IMG) Gene ID is provided for strain Wilcox, indicated by a star. Silva database accession numbers are included for all other sequences. The tree was constructed using the Alignment, Classification and Tree Service hosted at the SINA website ${ }^{23}$.

safe bioremediation technology for the treatment of saline PW will not only prevent unintended seismic activity and contamination of subsurface aquifers but also help offset the shortage of freshwater resources.

In this article we report the isolation of a halophilic bacterium from PW from Payne County, OK, USA. This organism is capable of degrading both aliphatic and aromatic compounds at high salinity. Although there are recent reports on the isolation and characterization of microorganisms that degrade petroleum compounds from contaminated saline environments ${ }^{15-20}$, to our knowledge very little is known about similar microorganisms living in $\mathrm{PW}^{21,22}$. Therefore, understanding the diversity, ecology, physiology and catabolic potential of such organisms is crucial for developing technologies for the remediation of saline PW for beneficial uses.

\section{Results}

General features of the draft genome and the phylogeny of strain Wilcox. The strain Wilcox genome consists of $3,584,069$ base pairs (bp) with an average $\mathrm{G}+\mathrm{C}$ content of $67.25 \%$ and with 3283 predicted protein-coding genes. Single copies of 5S and 23S, and two copies of 16S rRNA genes, are present along with 53 tRNA genes in the genome.

The isolate exhibited $>99 \% 16 \mathrm{~S}$ rRNA -gene nucleotide identity to that of Modicisalibacter tunisiensis strain LIT2 (Class Gammaproteobacteria, Family Halomonadaceae) that was isolated from oil-field water in Tunisia ${ }^{21}$. The isolate also showed $>99 \%$ sequence identity to a $16 \mathrm{~S}$ rRNA gene sequenced from an uncultured bacterium in San Juan Basin disposal site produced water (Silva accession number HQ893769). The members of the genus Modicisalibacter formed a distinct cluster from most closely related microbes in the genera Halomonas, Chromohalobacter, and Salincola, all members of family Halomonadaceae (Fig. 1). The isolate is tentatively designated as Modicisalibacter sp. strain Wilcox.

Prediction of hydrocarbon degrading genes in strain Wilcox. The genomic analysis of strain Wilcox provided the basis of hypotheses for hydrocarbon degradation mechanisms by the bacterium. Integrated Microbial Genomes (IMG) was the primary source of functional annotation information. We also used BLASTp to identify close homologs in the NCBI non-redundant protein database. Based on KEGG KO assignments and NCBI BLASTp search against NCBI nr, we predicted almost complete metabolic pathways for several aromatic compounds in silico in strain Wilcox genome (Table 1, Supplemental Table S2). Functional annotations suggested the presence of genes used for the metabolism of a variety of aromatic compounds and aliphatic compounds, including genes that code for oxygenases and dioxygenases such as phenol hydroxylase, salicylate hydroxylase, p-hydroxybezoate hydroxylase, 3-(3-hydroxy-phenyl) propionate/3-hydroxycinnamic acid hydroxylase, benzene 1,2-dioxygenasse, benzoate 1,2-dioxygenase, 2-halobenzoate 1,2-dioxygenase, and biphenyl dioxygenase alpha and beta subunits. These enzymes potentially catalyze the initial hydroxylation of a large variety of aromatic compounds into a few key central metabolic intermediates such as catechol, protocatechuate and gentisate ${ }^{9,24-26}$. In addition, genome analysis predicted most of the genes in the paa phenylacetate degradation pathway, by which phenylacetate is activated by a Co-A ligase and is then converted to ring-1, 2-epoxide by a multicomponent monooxygenase followed by a hydrolytic ring cleavage ${ }^{27-29}$. Interestingly, we did not find naphthalene and other polyaromatic hydrocarbon (PAH) related genes, such as genes that code for the upper pathway enzymes involved in the conversion of naphthalene to salicylate ${ }^{30}$.

The genome analysis predicted genes for aromatic ring cleavage enzymes such catechol 1,2-dioxygenase and protocatechuate 3,4-dioxygenase, two of the most common aromatic ring cleaving enzymes that produce oxygenolytic ring-cleavage products that enter central metabolism via beta-ketoadipate pathway, ${ }^{9,31}$. Most of the genes in beta-ketoadipate pathway were present on the genome (Table 1 and Supplemental Table S2).

In addition, the genome of strain Wilcox harbors some of the genes needed for the degradation of n-alkanes. For example, we detected the gene that codes for rubredoxin-NAD (+) reductase, one of the three components of alkane hydroxylase system (AlkB). In addition, analysis predicted the presence of alcohol dehydrogenase and 


\begin{tabular}{|c|c|c|c|c|c|c|}
\hline IMG Gene ID ${ }^{1}$ & Gene name & Putative function & Organism & $\%$ Identity & E-value & NCBI accession no \\
\hline 2844586937 & $b p h C$ & Biphenyl-2,3-diol 1,2-dioxygenase & Halomonas sp. A11-A & 92.6 & $0.00 \mathrm{E}+00$ & WP_110068217.1 \\
\hline 2844586938 & $b p h B$ & Cis-2,3-dihydrobiphenyl-2,3-diol dehydrogenase & Halomonas sp. A11-A & 94.93 & $0.00 \mathrm{E}+00$ & WP_110068218.1 \\
\hline 2844586939 & $b n z D$ & $\begin{array}{l}\text { Benzene 1,2-dioxygenase system ferredoxin-NAD(+) } \\
\text { reductase subunit }\end{array}$ & Halomonas sp. A11-A & 89 & $0.00 \mathrm{E}+00$ & WP_110068219.1 \\
\hline 2844586941 & bphA2 & Biphenyl dioxygenase subunit beta & Halomonas sp. A11-A & 84.95 & $2.00 \mathrm{E}-118$ & WP_110068221.1 \\
\hline 2844586942 & bphA1 & Biphenyl dioxygenase subunit alpha & Halomonas sp. A11-A & 94.3 & $0.00 \mathrm{E}+00$ & WP_110068222.1 \\
\hline 2844586958 & fadA & Acetyltransferase & Halomonas sp. 362.1 & 81.94 & $2.00 \mathrm{E}-78$ & WP_129138321.1 \\
\hline 2844587095 & ald & Long-chain aldehyde dehydrogenase & Halomonadaceae bacterium T82-2 & 96 & $0.00 \mathrm{E}+00$ & KXS36977.1 \\
\hline 2844587430 & $D O D A$ & 4,5-DOPA dioxygenase extradiol & Halomonas sp. EAR18 & 86.04 & $8.00 \mathrm{E}-170$ & WP_136065726.1 \\
\hline 2844587495 & $n a h G$ & Salicylate hydroxylase & Halomonadaceae bacterium T82-2 & 88.25 & $0.00 \mathrm{E}+00$ & KXS36864.1 \\
\hline 2844587528 & alkT & Rubredoxin-NAD(+) reductase & Halomonadaceae bacterium $\mathrm{T} 82-3$ & 99.74 & $0.00 \mathrm{E}+00$ & KXS38198.1 \\
\hline 2844588030 & menH & $\begin{array}{l}\text { 2-succinyl-6-hydroxy-2,4-cyclohexadiene-1-carboxylate } \\
\text { synthase }\end{array}$ & Halomonadaceae bacterium $\mathrm{T} 82-2$ & 95.83 & 0 & KXS36894.1 \\
\hline 2844588354 & $f a d A$ & 3-ketoacyl-CoA thiolase & Halomonas xianhensis & 84.65 & $0.00 \mathrm{E}+00$ & WP_134016041.1 \\
\hline 2844588659 & $p c a G$ & Protocatechuate 3,4-dioxygenase alpha chain & Halomonadaceae bacterium T82-2 & 95.22 & $1.00 \mathrm{E}-145$ & KXS38033.1 \\
\hline 2844588660 & pcaH & Protocatechuate 3,4-dioxygenase beta chain & Halomonadaceae bacterium T82-2 & 99.18 & $2.00 \mathrm{E}-180$ & KXS38034.1 \\
\hline 2844588668 & paaJ & 3-oxoadipyl-CoA/3-oxo-5,6-dehydrosuberyl-CoA thiolase & Halomonadaceae bacterium $\mathrm{T} 82-2$ & 97.51 & $0.00 \mathrm{E}+00$ & KXS38042.1 \\
\hline 2844588669 & pcaJ & 3-oxoadipate CoA-transferase subunit $B$ & Halomonadaceae bacterium T82-2 & 99.22 & $0.00 \mathrm{E}+00$ & KXS38043.1 \\
\hline 2844588670 & pcaI & 3-oxoadipate CoA-transferase subunit A & Halomonas sp. 362.1 & 94.85 & $0.00 \mathrm{E}+00$ & WP_129138993.1 \\
\hline 2844588671 & $p c a B$ & 3-carboxy-cis,cis-muconate cycloisomerase & Halomonadaceae bacterium T82-2 & 86.91 & $0.00 \mathrm{E}+00$ & KXS38045.1 \\
\hline 2844588678 & paaH & 3-hydroxyadipyl-CoA dehydrogenase & Halomonas sp. JS92-SW72 & 84.89 & $0.00 \mathrm{E}+00$ & WP_119023241.1 \\
\hline 2844588712 & nagL & Maleylpyruvate isomerase & Halomonadaceae bacterium T82-2 & 87.27 & $1.00 \mathrm{E}-133$ & KXS38997.1 \\
\hline 2844589229 & $a d h$ & Alcohol dehydrogenase & Halomonas sp. EAR18 & 88.46 & $3.00 \mathrm{E}-178$ & WP_136069176 \\
\hline 2844589416 & $\operatorname{ahp} C$ & Alkyl hydroperoxide reductase $\mathrm{C}$ & Halomonas coralii & 96.5 & $2.00 \mathrm{E}-140$ & WP_163649990.1 \\
\hline 2844589672 & $h m g A$ & Homogentisate 1,2-dioxygenase & Halomonadaceae bacterium T82-2 & 95.86 & $0.00 \mathrm{E}+00$ & KXS37722.1 \\
\hline 2844589728 & paaE & 1,2-phenylacetyl-CoA epoxidase, subunit E & Halomonas sp. HAL1 & 70.47 & $0.00 \mathrm{E}+00$ & WP_008957201.1 \\
\hline 2844589730 & paac & 1,2-phenylacetyl-CoA epoxidase, subunit C & Halomonas sp. JS92-SW72 & 79.92 & $1.00 \mathrm{E}-150$ & WP_119023124.1 \\
\hline 2844589731 & paaB & 1,2-phenylacetyl-CoA epoxidase, subunit B & Halomonas bacterium & 89.25 & $2.00 \mathrm{E}-57$ & WP_022521442.1 \\
\hline 2844589732 & paaA & 1,2-phenylacetyl-CoA epoxidase, subunit A & unclassified Halomonas & 90.99 & $0.00 \mathrm{E}+00$ & WP_027958342.1 \\
\hline 2844589733 & paaK & Phenylacetate-coenzyme A ligase & Halomonas pacifica & 83.52 & $0.00 \mathrm{E}+00$ & WP_146804038.1 \\
\hline 2844589734 & $p c a F$ & Beta-ketoadipyl-CoA thiolase & Halomonas sp. 3(2) & 87.53 & $0.00 \mathrm{E}+00$ & WP_151442119.1 \\
\hline 2844589737 & paaG & 1,2-epoxyphenylacetyl-CoA isomerase & Halomonas sp. JS92-SW72 & 80.99 & $8.00 \mathrm{E}-156$ & WP_119023117.1 \\
\hline 2844589738 & paaF & 2,3-dehydroadipyl-CoA hydratase & Halomonas sp. 3(2) & 80.47 & $1.00 \mathrm{E}-144$ & WP_151442123.1 \\
\hline 2844589751 & catB-1 & Muconate cycloisomerase 1 & Halomonadaceae bacterium T82-2 & 94.1 & $1.00 \mathrm{E}-133$ & KXS37865.1 \\
\hline 2844589752 & catB-2 & Muconate cycloisomerase 1 & Halomonas heilongjiangensis & 92 & $9.00 \mathrm{E}-63$ & PXX89496.1 \\
\hline 2844589753 & catC & Muconolactone Delta-isomerase & Halomonadaceae bacterium T82-2 & 97.92 & $3.00 \mathrm{E}-64$ & KXS37864.1 \\
\hline 2844589754 & catA & Catechol 1,2-dioxygenase & Halomonas nitroreducens & 85.49 & 0 & WP_126480973.1 \\
\hline 2844589755 & benA & 2-halobenzoate 1,2-Fgenase large subunit & Halomonadaceae bacterium T82-2 & 100 & $1.00 \mathrm{E}-109$ & KXS37862.1 \\
\hline 2844589756 & benB & 2-halobenzoate 1,2-dioxygenase small subunit & unclassified Halomonas & 91.98 & $1.00 \mathrm{E}-109$ & WP_078089514.1 \\
\hline 2844589757 & benC & Benzoate 1,2-dioxygenase electron transfer component & unclassified Halomonas & 91.98 & 0 & WP_078089514.1 \\
\hline 2844589758 & benD & $\begin{array}{l}\text { 1,6-dihydroxycyclohexa-2,4-diene-1-carboxylate dehy- } \\
\text { drogenase }\end{array}$ & Halomonas aestuarii & 85.6 & $1.50 \mathrm{E}-159$ & WP_163650312.1 \\
\hline 2844589848 & $p o b A$ & p-hydroxybenzoate hydroxylase & Halomonas coralii & 92.64 & 0 & WP_129140614.1 \\
\hline 2844589969 & fadI & Acetyl-CoA acetyltransferase & Halomonadaceae bacterium T82-2 & 98.47 & $0.00 \mathrm{E}+00$ & KXS37177.1 \\
\hline 2844590194 & $m p h P$ & Phenol hydroxylase P5 protein & Marinobacter pelagius & 80.73 & $7.00 \mathrm{E}-47$ & WP_113861973.1 \\
\hline
\end{tabular}

Table 1. Putative functions and top homologs of Modicisalibacter sp. strain Wilcox genes predicted to encode proteins involved in metabolism of hydrocarbons. ${ }^{1}$ Gene sequences were BLAST p searched against NCBI nr database in NCBI for top homologs.

aldehyde dehydrogenase, suggesting the organism's potential to metabolize n-alkanes through oxidation of the terminal methyl group to the corresponding primary alcohol and then to fatty acids, which enter beta-oxidation steps for complete metabolism. While we did not find a homolog of alkane monooxygenase of the AlkB complex, we surmise the presence of other genes, possibly a novel gene or mechanism responsible for the initial oxidation of $\mathrm{n}$-alkanes to the corresponding alcohols.

Genome prediction of heavy metal resistance in strain Wilcox. Microorganisms possess various resistance mechanisms against toxic heavy metals such as active efflux systems, bioaccumulation and enzymatic 


\begin{tabular}{|c|c|c|c|c|c|c|}
\hline IMG Gene ID $^{1}$ & Gene name & Putative Function & Organism & \% Identity & E-value & NCBI accession no \\
\hline 2844587032 & acr3 & $\begin{array}{l}\text { Arsenical-resistance } \\
\text { protein }\end{array}$ & Halomonas xianhensis & 100 & 0 & WP_092850561.1 \\
\hline 2844587034 & ars $C_{-} 1$ & Arsenate reductase & Halomonas xianhensis & 100 & $9.00 \mathrm{E}-95$ & WP_092850563.1 \\
\hline 2844587035 & arsC_2 & Protein ArsC & Halomonas xianhensis & 100 & $8.00 \mathrm{E}-98$ & WP_092850567.1 \\
\hline 2844587328 & $c z c D$ & $\begin{array}{l}\text { Cadmium, cobalt and } \\
\text { zinc/H( }(+)-\mathrm{K}(+) \text { anti- } \\
\text { porter }\end{array}$ & $\begin{array}{l}\text { Halomonadaceae bacte- } \\
\text { rium } \mathrm{T} 82-2\end{array}$ & 98.73 & $0.00 \mathrm{E}+00$ & KXS37941.1 \\
\hline 2844587374 & $m n t B$ & $\begin{array}{l}\text { Manganese transport sys- } \\
\text { tem membrane protein }\end{array}$ & $\begin{array}{l}\text { Halomonadaceae bacte- } \\
\text { rium T82-2 }\end{array}$ & 94.61 & $0.00 \mathrm{E}+00$ & KXS36360.1 \\
\hline 2844587477 & merA & Mercuric reductase & $\begin{array}{l}\text { Marinobacter daqiaon- } \\
\text { ensis }\end{array}$ & 91 & 0 & WP_092012523.1 \\
\hline 2844587480 & cop $A \_1$ & $\begin{array}{l}\text { Copper-exporting P-type } \\
\text { ATPase }\end{array}$ & Marinobacter salarius & 94.67 & $0.00 \mathrm{E}+00$ & WP_085682201.1 \\
\hline 2844587740 & $\operatorname{ars} A$ & $\begin{array}{l}\text { Arsenical pump-driving } \\
\text { ATPase }\end{array}$ & $\begin{array}{l}\text { Halomonadaceae bacte- } \\
\text { rium T82-2 }\end{array}$ & 100 & 0 & KXS39846.1 \\
\hline 2844587781 & copA_2 & $\begin{array}{l}\text { Copper-exporting P-type } \\
\text { ATPase }\end{array}$ & $\begin{array}{l}\text { Halomonadaceae bacte- } \\
\text { rium T82-2 }\end{array}$ & 93.61 & $0.00 \mathrm{E}+00$ & KXS39808.1 \\
\hline 2844587847 & copA_3 & $\begin{array}{l}\text { Copper-exporting P-type } \\
\text { ATPase }\end{array}$ & $\begin{array}{l}\text { Halomonadaceae bacte- } \\
\text { rium T82-2 }\end{array}$ & 91.27 & $0.00 \mathrm{E}+00$ & KXS39748.1 \\
\hline 2844587870 & $m n t P$ & $\begin{array}{l}\text { putative manganese efflux } \\
\text { pump }\end{array}$ & Halomonas sp. 362.1 & 83.07 & $2.00 \mathrm{E}-99$ & WP_129141166.1 \\
\hline 2844588193 & zur & $\begin{array}{l}\text { Zinc uptake regulation } \\
\text { protein }\end{array}$ & $\begin{array}{l}\text { Halomonadaceae bacte- } \\
\text { rium T82-2 }\end{array}$ & 96 & $7.00 \mathrm{E}-99$ & KXS39292.1 \\
\hline 2844588553 & $z n t B$ & Zinc transport protein & $\begin{array}{l}\text { Halomonadaceae bacte- } \\
\text { rium T82-2 }\end{array}$ & 98.5 & $0.00 \mathrm{E}+00$ & KXS38423.1 \\
\hline 2844588586 & $z n t A$ & $\begin{array}{l}\text { Zinc/cadmium/lead- } \\
\text { transporting P-type } \\
\text { ATPase }\end{array}$ & $\begin{array}{l}\text { Halomonadaceae bacte- } \\
\text { rium T82-2 }\end{array}$ & 97.4 & $0.00 \mathrm{E}+00$ & KXS38456.1 \\
\hline 2844589668 & $\operatorname{ars} B$ & $\begin{array}{l}\text { Arsenical pump mem- } \\
\text { brane protein }\end{array}$ & Halomonas sp. SL1 & 87.82 & 0 & WP_107181297.1 \\
\hline 2844589669 & arsC_3 & Arsenate reductase & $\begin{array}{l}\text { Halomonadaceae bacte- } \\
\text { rium T82-2 }\end{array}$ & 91.18 & $8.00 \mathrm{E}-84$ & KXS37725.1 \\
\hline 2844589689 & $\operatorname{ctp} C$ & $\begin{array}{l}\text { putative manganese/zinc- } \\
\text { exporting P-type ATPase }\end{array}$ & $\begin{array}{l}\text { Halomonadaceae bacte- } \\
\text { rium T82-2 } \\
\end{array}$ & 94.96 & $0.00 \mathrm{E}+00$ & KXS37705.1 \\
\hline 2844589846 & mco & Multicopper oxidase & $\begin{array}{l}\text { Halomonadaceae bacte- } \\
\text { rium T82-2 }\end{array}$ & 99.57 & $0.00 \mathrm{E}+00$ & KXS37229.1 \\
\hline 2844589924 & $\operatorname{cor} C$ & $\begin{array}{l}\text { Magnesium and cobalt } \\
\text { efflux protein CorC }\end{array}$ & $\begin{array}{l}\text { Halomonadaceae bacte- } \\
\text { rium T82-2 }\end{array}$ & 98.97 & $1.00 \mathrm{E}-146$ & KXS39516.1 \\
\hline 2844590090 & $c b i X$ & $\begin{array}{l}\text { Sirohydrochlorin cobalto- } \\
\text { chelatase }\end{array}$ & $\begin{array}{l}\text { Halomonadaceae bacte- } \\
\text { rium T82-2 }\end{array}$ & 91.27 & $1.00 \mathrm{E}-74$ & KXS38081.1 \\
\hline
\end{tabular}

Table 2. Putative functions and top homologs of Modicisalibacter sp. strain Wilcox genes predicted to encode proteins involved in heavy metal resistance. ${ }^{1}$ Gene sequences were BLAST p searched against NCBI nr database in NCBI for top homologs.

reduction $^{32}$. Produced water are naturally enriched with a variety of heavy metals depending on the formation geology, age of the oil well, and oil extraction activities ${ }^{33}$. Genome analysis indicated the presence of a collection of putative metal-exporting and other resistance systems that might facilitate the survival of strain Wilcox in heavy metals containing PW, including several P-type ATPases, efflux pumps, antiporters, and transport proteins and other mechanisms responsible for removing metal ions out of the cells (Table 2 and Supplemental Table S3). We found genes that code for P-type ATPases for copper, zinc, cadmium, lead, manganese and efflux pumps for manganese and cobalt in the genome. P-type ATPases comprise a large protein family that pump out a variety of heavy metal ions and lipids across cellular membranes ${ }^{34,35}$. We predicted arsenic detoxification genes ars $C_{-} 1$, ars $C \_2$, and $a r s C \_3$ that code for arsenate reductases in strain Wilcox's genome. In addition, we found genes for arsenical pump membrane protein ArsB and arsenical-resistance protein Acr3. These systems catalyze reduction of As (V) to As (III) by arsenate reductase which then can be expelled from the cell by an efflux pump ${ }^{36,37}$. Similarly, mercuric reductase gene, merA was found on the genome. Mercuric reductase reduces ionic mercury $\left(\mathrm{Hg}^{2+}\right)$ into the less toxic metallic mercury $\left(\mathrm{Hg}^{\circ}\right)$ form, which then evaporates ${ }^{38,39}$. Overall, strain Wilcox is endowed with robust heavy metal resistance system.

Genome-guided laboratory validation of the hydrocarbon degradation capacity of strain Wilcox. The genome analysis of strain Wilcox predicted a repertoire of hydrocarbon degrading genes. Genomeguided laboratory culture studies were initiated to corroborate the genome predicted catabolic potential of strain Wilcox to degrade important hydrocarbons. Table 3 shows the strain's ability to degrade both monoaromatic hydrocarbons (MAH), biphenyls, PAHs as well as n-alkanes. Our culture studies revealed that strain Wilcox is capable of degrading all tested MAH such as benzene, toluene, ethylbenzene, and xylenes (BTEX) as well as, 


\begin{tabular}{|c|c|c|c|}
\hline Hydrocarbon class & Hydrocarbons tested as substrate ${ }^{\text {a }}$ & Genome predicted degradation & $\begin{array}{l}\text { Experimental validation of } \\
\text { biodegradation }\end{array}$ \\
\hline \multirow[t]{8}{*}{ MAH } & Benzene $(20-40 \mu \mathrm{mol} / \mathrm{bottle})$ & + & + \\
\hline & Toluene $(20-40 \mu \mathrm{mol} / \mathrm{bottle})$ & + & + \\
\hline & Ethylbenzene (20 -30 $\mu \mathrm{mol} / \mathrm{bottle})$ & + & + \\
\hline & Xylenes $(20-30 \mu \mathrm{mol} / \mathrm{bottle})$ & + & + \\
\hline & BTEX (combined) & + & + \\
\hline & Phenol (2 mM) & + & + \\
\hline & Benzoate (1-2 mM) & + & + \\
\hline & Phenylacetate $(2 \mathrm{mM})$ & + & + \\
\hline Biphenyl & Biphenyl (2 mM) & + & + \\
\hline \multirow[t]{2}{*}{ PAH } & Naphthalene (1-2 mM) & - & - \\
\hline & Phenanthrene (1-2 mM) & - & - \\
\hline \multirow[t]{6}{*}{ n-Alkanes } & Methane (100 uM) & - & - \\
\hline & Hexane $(5 \mathrm{mM})$ & - & - \\
\hline & Decane $(2 \mathrm{mM})$ & + & + \\
\hline & Hexadecane $(5 \mathrm{mM})$ & + & + \\
\hline & Eicosane $(2 \mathrm{mM})$ & $--^{b}$ & - \\
\hline & Dotriacontane $(2 \mathrm{mM})$ & $-\mathbf{b}$ & - \\
\hline
\end{tabular}

Table 3. Laboratory assessment of the biodegradation ability of strain Wilcox. Strain Wilcox grown in mineral salts medium supplemented with $2.5 \mathrm{M} \mathrm{NaCl}$ and amended with a hydrocarbon as the sole source of carbon and energy were used to study the degradation potential of strain Wilcox. Cultures were inoculated with approximately $5 \times 10^{5}$ or $1.2 \times 10^{6} \mathrm{CFU}$ of strain Wilcox. ${ }^{\mathrm{a}} \mathrm{BTEX}$ compounds and methane were determined using a gas chromatograph ${ }^{40,41}$. Degradation activities on biphenyl, phenol, phenylacetate, $\mathrm{n}$-hexane, $\mathrm{n}$-decane, $\mathrm{n}$-hexadecane, $\mathrm{n}$-eicosane, and $\mathrm{n}$-dotriacontane were determined as CFU. Benzoate degradation was monitored using absorption at $223 \lambda$ using a spectrometer. ${ }^{\mathbf{b}} \mathrm{We} \operatorname{did}$ not identify homologs of almA or ladA genes known to act on longer-chain alkanes. (+) Degraded as the sole carbon and energy source. ( - ) No growth or degradation. The data points are averages of triplicate bottles.

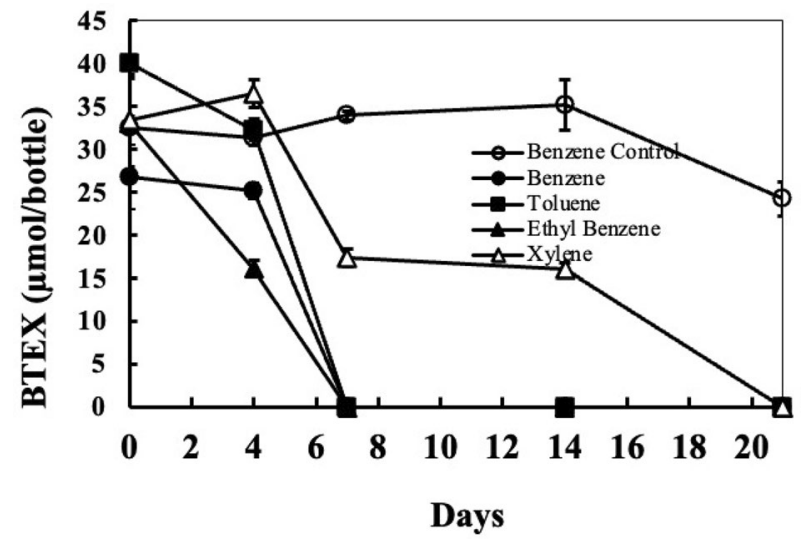

Figure 2. The profile of BTEX degradation in MSM containing $2 \mathrm{M} \mathrm{NaCl}$. Cultures containing $49 \mathrm{ml}$ of MSM supplemented with $2 \mathrm{M} \mathrm{NaCl}$ were set up. Cultures were spiked with BTEX and inoculated with $1 \mathrm{ml}\left(5 \times 10^{5} \mathrm{CFU}\right)$ of strain Wilcox. Culture bottles were closed with Teflon-coated septa and aluminum crimps. Un-inoculated controls were prepared similarly (only benzene is shown). BTEX concentrations were determined by injecting $100 \mu \mathrm{L}$ of headspace sample into a gas chromatograph (GC) at given time points. Error bars indicate \pm 1 standard deviation of triplicate bottles $(n=3)$.

phenol, benzoate, biphenyl, and phenylacetate as the sole sources of carbon at high salinity. However, no degradation of PAHs such as naphthalene and phenanthrene occurred even after four weeks of incubation under similar growth conditions. Strain Wilcox was also capable of degrading n-decane and n-hexadecane as the sole sources of carbon and energy at high salinity (Supplemental Fig. S1 and S2). However, no apparent degradation of smaller-chain alkanes such as methane and hexane or of longer-chain alkanes such as n-eicosane and n-dotriacontane occurred after four weeks of incubation under similar growth conditions.

Figure 2 shows degradation kinetics of BTEX compounds in mineral salts medium (MSM) supplemented with $2 \mathrm{M} \mathrm{NaCl}^{42}$. Complete degradation of benzene, toluene, and ethylbenzene occurred in 7 days at a rate of approximately 4-6 $\mu$ mole/day. Degradation of xylene proceeded after a lag of 4 days and took almost 17 days 

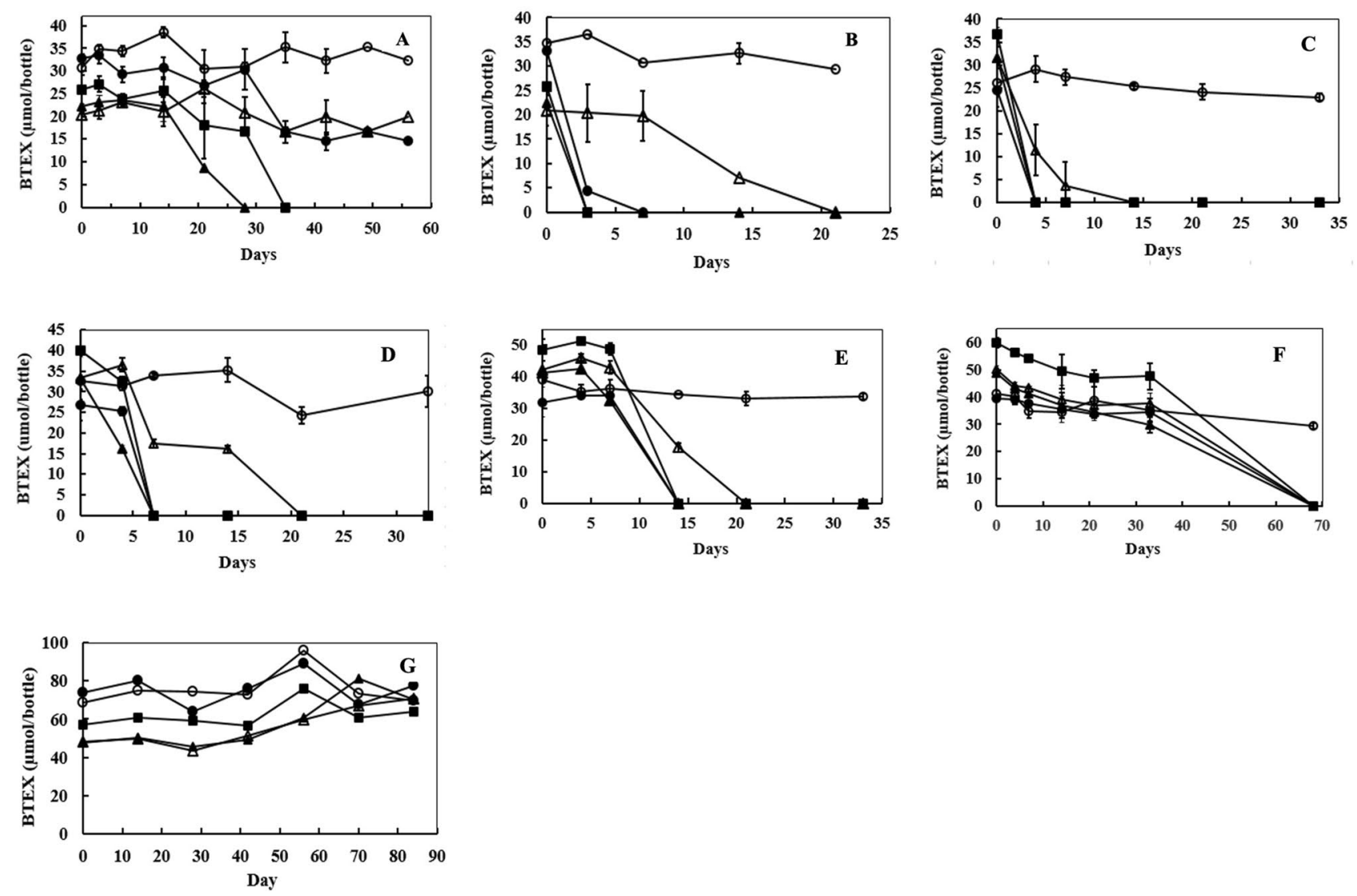

Figure 3. Degradation of BTEX by strain Wilcox at varied salt concentrations. Culture bottles contained $48 \mathrm{ml}$ MSM supplemented with (A), $0.016 \mathrm{M} \mathrm{NaCl}$; (B), $0.5 \mathrm{M} \mathrm{NaCl}$; (C), $1.0 \mathrm{M} \mathrm{NaCl}$; (D), $2.0 \mathrm{M} \mathrm{NaCl} ;(\mathbf{E}), 3.0 \mathrm{M}$ $\mathrm{NaCl} ;(\mathbf{F}), 4.0 \mathrm{M} \mathrm{NaCl}$ or $(\mathbf{G}), 5.0 \mathrm{M} \mathrm{NaCl}$. Cultures were inoculated with $2 \mathrm{ml}$ (approximately $1.2 \times 10^{6} \mathrm{CFU}$ ) of strain Wilcox culture and closed with Teflon-coated septa and aluminum crimps. Un-inoculated controls were prepared similarly (only data for benzene is shown). Relatively higher amounts of BTEX were measured in the headspace in bottles with high salt concentrations ( 4 and $5 \mathrm{M} \mathrm{NaCl}$ ) suggesting lower solubility of these compounds at higher salinity. Symbols: Benzene Control (- $\bigcirc-)$; Benzene $\left(-\mathbf{O}_{-}\right)$; Toluene $(-\mathbf{\square}-)$; Ethylbenzene $(-\boldsymbol{\Delta}-)$; and Xylenes $(-\Delta-)$. Error bars indicate \pm 1 standard deviation of triplicate bottles $(n=3)$.

thereafter for complete mineralization at a rate of roughly $2.15 \mu$ mole/day. These results clearly show the ability of strain Wilcox to degrade some of the most problematic hydrocarbons.

We evaluated the strain's ability to degrade BTEX in MSM at salt concentrations ranging from $0.016 \mathrm{M}$ to $5 \mathrm{M}$ $\mathrm{NaCl}$ (Fig. 3). Complete degradation of BTEX occurred in the presence of 0.5 to $4 \mathrm{M} \mathrm{NaCl}$ (Fig. 3B-F) with most rapid degradation at $1 \mathrm{M} \mathrm{NaCl}$. Interestingly, as seen in Fig. $3 \mathrm{~A}$, degradation proceeded at much slower rates in the presence of the lowest concentration of $\mathrm{NaCl}(0.016 \mathrm{M} \mathrm{NaCl})$. Ethylbenzene and toluene were completely degraded in 4 and 5 weeks, but little degradation of benzene or xylene was seen during the same time periods suggesting perhaps different enzymes may be responsible for the degradation of toluene and ethylbenzene compared to benzene and xylenes. BTEX degradation in the presence of $4 \mathrm{M} \mathrm{NaCl}$ (Fig. 3F) was slow, requiring 70 days for complete degradation, while no degradation occurred in the presence of $5 \mathrm{M} \mathrm{NaCl}$ even after incubating for $>12$ weeks (Fig. 3G). To determine the viability of cells after 12 weeks of incubation at $5 \mathrm{M} \mathrm{NaCl}$, we plated these cells on agar plates prepared with $5 \mathrm{mM}$ acetate and $1 \mathrm{M} \mathrm{NaCl}$. No colonies appeared on the plates, suggesting cells were completely killed at $5 \mathrm{M} \mathrm{NaCl}$.

Figure 4 shows the rate of BTEX degradation at varied salt concentrations. Results show that among BTEX, toluene was degraded most rapidly $(9.2 \mu \mathrm{mol} /$ day $)$ at all $\mathrm{NaCl}$ concentrations, followed by ethylbenzene $(8 \mu \mathrm{mol} /$ day), benzene $(6.1 \mu \mathrm{mol} /$ day $)$, and xylenes $(2.25 \mu \mathrm{mol} /$ day $)$. In addition to BTEX, strain Wilcox also utilizes benzoate, phenol, biphenyl, and phenylacetate as the sole sources of carbon and energy at $2.5 \mathrm{M} \mathrm{NaCl}$. Complete degradation of benzoate occurred in 4 weeks and no degradation benzoate occurred in un-inoculated flasks (Supplemental Fig. S3). Complete degradation of benzoate took longer than any other aromatic compound tested, which might be due to toxic nature of benzoate. Growth on phenol, biphenyl, and phenylacetate was determined as CFU and results show an increase in cell numbers by at least 3-4 log units from an initial $10^{3}$ or $10^{4} \mathrm{CFU} / \mathrm{ml}$ within one to two weeks (Supplemental Fig. S4, S5, and S6).

Bioaugmentation of PW by strain Wilcox. We assessed strain Wilcox's ability to survive and degrade amended BTEX compounds directly in PW collected from the First Wilcox formation in Payne County, OK. Results (Fig. 5) show the strain's ability to degrade BTEX compounds when provided individually or as a mix- 


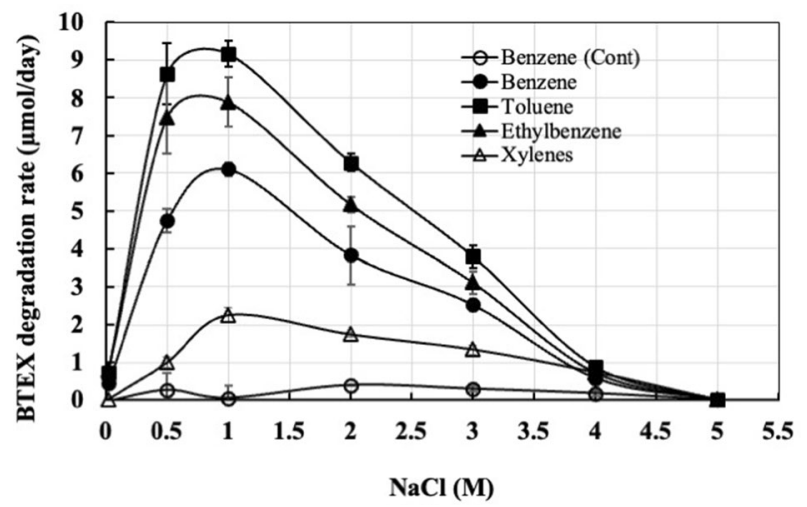

Figure 4. BTEX degradation rates in the presence of different salt $(\mathrm{NaCl})$ concentration. Optimal degradation of BTEX degradation occurred at $1 \mathrm{M} \mathrm{NaCl}$. The rates of BTEX compounds increased initially reaching maximum at $1 \mathrm{M} \mathrm{NaCl}$ and the rate decreased progressively with increasing $\mathrm{NaCl}$ concentration. No degradation of BTEX occurred in bottles containing $5 \mathrm{M} \mathrm{NaCl}$ over 12 weeks of incubation. Error bars indicate \pm 1 standard deviation of triplicate bottles $(n=3)$.

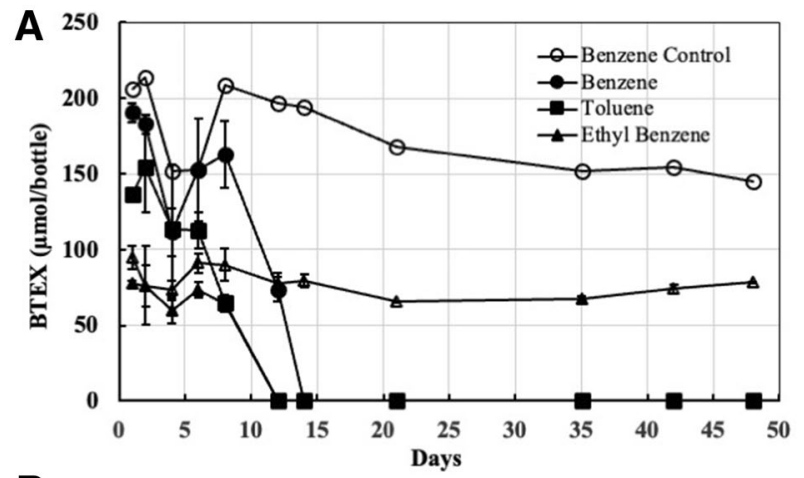

\section{B}

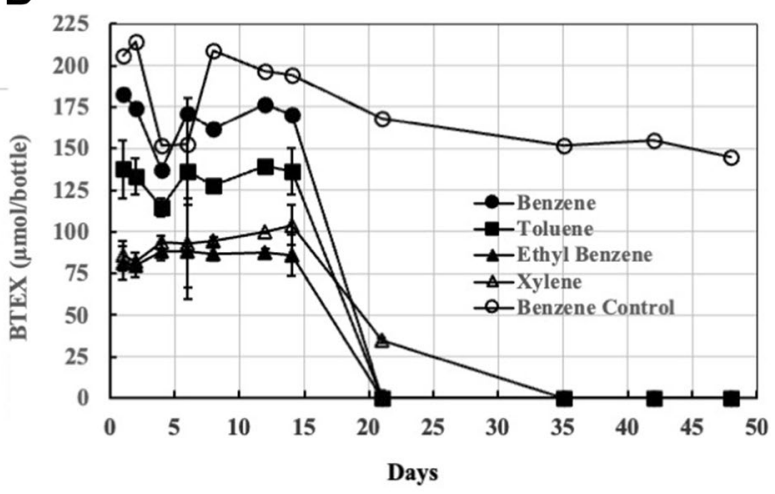

Figure 5. Degradation of BTEX in PW (no nutrients except the added hydrocarbons) as the sole source (s) of carbon amended individually (A) and together (B). Microcosms containing $48 \mathrm{ml}$ of formation PW were inoculated with $2 \mathrm{ml}$ (roughly $1.2 \times 10^{6} \mathrm{CFU}$ ) of strain Wilcox and closed with Teflon-coated septa and aluminum crimps. Autoclaved control microcosms amended with benzene, toluene, ethylbenzene and/or xylenes were prepared similarly (only benzene data is shown). Degradation of BTEX was monitored at time points by injecting $100 \mu \mathrm{L}$ headspace samples into onto a GC. Error bars indicate \pm 1 standard deviation of triplicate bottles $(n=3)$.

ture. The organism degraded benzene, toluene or ethylbenzene as the sole source carbon within 12-14 days and no degradation of added xylene occurred even after incubating for 48 days (Fig. 5A). No or little degradation of added hydrocarbons occurred in control bottles containing PW not bioaugmented with strain Wilcox. These results clearly show the organism's potential to degrade hydrocarbons in PW at high concentrations. Degradation proceeded after a longer lag time when BTEX compounds were added together (Fig. 5B). Complete degradation 
of benzene, toluene, and ethylbenzene occurred in 21 days compared to 12-14 day when these compounds were fed individually. The longer lag time could be due to overall higher concentrations of BTEX when fed together. Interestingly, added xylene was completely degraded in 35 days when BTEX were fed together compared to when these compounds were fed individually (Fig. 5A), suggesting that xylene is degraded by enzymes induced by the presence of benzene, toluene, and/or ethylbenzene and is not able to induce for its own metabolism.

\section{Discussion}

Large amounts of PWs are generated each year during oil and gas production operations and these wastewaters with complex physio-chemical properties pose a serious water management challenges and remediation is costly ${ }^{43}$. There is great interest in developing promising biological strategies for the remediation and reuse of PW after desalination, especially in the South-central and Western United States, where water scarcity has become a serious concern.

Biodegradation of hydrocarbons in PW is difficult or even impossible by traditional non-halophilic microorganisms due to high salinity and other toxicities. Halophiles or halotolerant microorganisms with hydrocarbon degradation capacity, on the other hand, are promising candidates for the bioremediation of hydrocarbons in PW. Recent studies have shown the biodegradation potential of halophiles and halotolerant bacteria and archaea in contaminated saline environments such as oilfields, (semi)-arid coastal regions, salt lakes, sabkhas, and others ${ }^{15-20,44}$. However, such information is seriously lacking for PW, despite the staggeringly large volumes of highly saline PW generated all over the world. Therefore, studies are urgently needed that explore microbes that can survive high salinity and able to mineralize petroleum compounds in PW.

Genome prediction of major hydrocarbon degradation pathways in Strain Wilcox. In this article, we report the isolation and characterization of a halophilic bacterium, Modicisalibacter sp. strain Wilcox from PW that is capable of degrading a variety of petroleum compounds at high salinity. We predicted in silico nearly complete metabolic pathways for a number of hydrocarbons in strain Wilcox genome. For example, we detected genes for several monooxygenases and dioxygenases that hydroxylate aromatic compounds to a few common intermediates such as catechol, protocatechuate, and gentisate ${ }^{9,24-26}$. Also, we predicted genes for ring cleavage enzymes such as catechol 1,2 dioxygenase and protocatechuate 3,4-dioxygenase that produce dearomatized products that are further degraded by the genes in the beta-ketoadipate pathway to central metabolites that enter the TCA cycle ${ }^{9,31}$ (Table 1). In addition, genome analysis predicted most of the genes in the paa phenylacetate degradation pathway that combines steps from aerobic and anaerobic catabolism of aromatic compounds. Genome analysis also predicted genes needed for the oxidation of medium-chain $n$-alkanes to the corresponding fatty acid that are further oxidized by beta-oxidation. These diverse and complete pathways suggest strain Wilcox has broad degradation abilities and is well suited for biodegradation of complex hydrocarbon mixtures at high salinity. These observations are consistent with other halophiles isolated from a variety of high salinity environments. (15-20).

At low concentrations, heavy metals are essential for cell survival and function, but become toxic when present at high concentration ${ }^{39}$. Microorganisms possess various resistance mechanisms against toxic heavy metals such as active efflux, bioaccumulation, and enzymatic reduction ${ }^{32}$. Many metal ions such as lead, cadmium, mercury, and aluminum have no biological role and exert inhibitory effects on cells by replacing essential metals from their natural binding sites, disrupting cell membranes, altering enzyme specificity, and denaturing DNA ${ }^{32,39}$. PWs are naturally enriched with a variety of heavy metals depending on the formation geology, age of the oil well, and oil extraction activities ${ }^{33}$. Genome analysis indicated the presence of a collection of putative metal-exporting and other resistance systems that might facilitate the survival of strain Wilcox in PW containing heavy metals. For example, we found genes that code for several P-type ATPases, efflux pumps, antiporters, transport proteins, and other mechanisms responsible for removing metal ions (Table 2). The genome analysis also predicted genes that code for arsenic and mercuric resistance systems. Altogether, these results indicate that strain Wilcox is endowed with robust heavy metal resistance capabilities. It is not surprising to find the presence of different mechanisms to cope with several heavy metals in strain Wilcox because PW are rich in a variety of heavy metals, some at high concentrations presumably from crude oil ${ }^{45,46}$. These findings are consistent with other halophiles that possess robust metal resistance mechanisms, as these organisms live in hypersaline environment where a variety of heavy metals accumulate due to agriculture, mining, industrial activities ${ }^{47}$.

Laboratory validation of genome-predicted hydrocarbon degradation potential in strain Wilcox. Laboratory cultures studies confirmed that the strain was able to completely mineralize BTEX within 7 days in MSM at $2 \mathrm{M} \mathrm{NaCl}$ with no lag time, with the exception of xylene, which took almost 21 days (Fig. 2). We further assessed the strain's ability to degrade BTEX in the presence of various salt concentrations (Fig. 3). These laboratory studies showed that the strain was able to degrade BTEX over a wide range of salinity ranging from 0.016 to $4 \mathrm{M} \mathrm{NaCl}$, with optimum degradation at $1 \mathrm{M} \mathrm{NaCl}$. No degradation of BTEX occurred at $5 \mathrm{M} \mathrm{NaCl}$ even after 3 months of incubation. When we plated cells from these cultures, no colonies appeared, suggesting complete death of strain Wilcox at $5 \mathrm{M} \mathrm{NaCl}$. Degradation proceeded at much slower rates under low salinity $(0.016 \mathrm{M} \mathrm{NaCl})$, suggesting strain Wilcox is a true halophile that requires high salinity for growth. Previous studies have shown both negative and positive impacts of salt on hydrocarbon degradation ability by microorganisms ${ }^{18}$. Estimation of the rate of BTEX degradation by strain Wilcox at different salinities suggest that toluene was degraded fastest, followed by ethylbenzene, benzene, and xylenes when fed together (Fig. 4). We found that strain Wilcox degraded BTEX at maximal rates at $1 \mathrm{M} \mathrm{NaCl}$, and the rate progressively decreased with increasing salt concentration. Previous studies using strain Seminole grown under similar conditions showed that strain Seminole degraded benzene optimally at a rate of $2.5 \mu \mathrm{mol} / \mathrm{bottle}$ compared to $6 \mu \mathrm{mol} / \mathrm{bottle}$ by strain 
Wilcox suggesting superior rate by strain Wilcox ${ }^{48}$. The strain's ability to degrade BTEX over a wide salinity range could be beneficial, as PW contain varying levels of salinities depending on the source and geology. Strain Wilcox also degraded other aromatic compounds such as phenol, biphenyl, benzoate, and phenylacetate, which is important, as most PW contain a variety of aromatic compounds along with BTEX, which are more problematic than many other hydrocarbons. Similar observations have been made in many halophilic and halotolerant hydrocarbon-degrading microorganisms from contaminated high salinity environments ${ }^{16,17,19,44,48,49}$.

Genome analysis predicted the presence of $m p h P$ and $b n z D$ genes that code for ring hydroxylating monooxygenases and dioxygenases such as phenol hydroxylase and benzene 1,2-dioxygenase, respectively. We surmise that these mono and dioxygenases may be responsible for the initial hydroxylation of benzene, toluene, ethylbenzene, xylenes, and phenol to central metabolites such as catechol ${ }^{50,51}$. The strain also degrades benzoate as the sole source of carbon, which is consistent with the presence of corresponding benzoate metabolic genes such as ben $A B C$, which code for a benzoate 1,2-dioxygenase complex that converts benzoate to cis-1,6-dihydroxy2,4-cyclohexadiene-1-carboxylic acid which is then converted to catechol by 1,6-dihydroxycyclohexa-2,4-diene1 -carboxylate dehydrogenase coded by benD gene ${ }^{52}$.

Strain Wilcox rapidly degraded biphenyl when presented as sole carbon and energy source. Biphenyl degradation is consistent with the presence of genes needed for the upper biphenyl degradation steps. We found homologs of $b p h A 1$ and $b p h A 2$, which code for biphenyl dioxygenase alpha and beta subunits that catalyze the oxidation of biphenyl to a dihydrodiol compound (2,3-dihydroxy-4-phenylhexa-4,6-diene) which is then converted to a dihydroxy compound (2,3-dihydroxybiphenyl) by cis-2,3-dihydrobiphenyl-2,3-diol dehydrogenase encoded by $b p h B$, also detected on the genome. The dihydroxy-compound is then degraded to 2-hydroxy-6-oxo-6-phenylhexa-2, 4 -dienoic acid by the ring-cleavage dioxygenase biphenyl-2,3-diol 1,2-dioxygenase encoded by bphC gene ${ }^{53}$. We did not detect a $b p h D$ gene homolog in strain Wilcox genome, which is responsible for the final conversion of the ring-cleavage product to benzoic acid and 2-hydroxypenta-2, 4-dienoic acid. We hypothesize this step may be catalyzed by other genes in the genome and benzoate formed in this step can be further oxidized to catechol by benzoate 1,2-dioxygenase encoded by ben $A B C$ and 1,6-dihydroxycyclohexa-2,4-diene-1-carboxylate dehydrogenase encoded by ben $D$, each of which were detected in the genome ${ }^{52}$.

Catechol produced from BTEX, phenol, benzoate and biphenyl can likely undergo ring cleavage by catechol 1,2-dioxygenase, encoded by the cat $A$ gene found on the genome. The ring cleavage compounds are further degraded by genes in the catechol branch of the beta-ketoadipate pathway, ${ }^{9,31}$. Most of these genes needed for the downstream steps are predicted to be present in strain Wilcox genome (Table 1 and Supplemental Table S2).

Strain Wilcox also degrades phenylacetate in accordance with the presence of requisite genes on the genome. The gene paaK codes for phenylacetate-CoA ligase that converts phenylacetate to phenylacetate-CoA which undergoes ring epoxidation by a multicomponent monooxygenase coded by a paaABCE gene cluster. The reactive and unstable epoxide is further isomerized to oxepin-CoA by the ring-1,2-epoxyphenylacetyl-CoA isomerase coded by paaG gene. This is followed by hydrolytic cleavage and beta-oxidation-like steps yielding acetyl-CoA and succinyl-CoA that enter TCA cycle ${ }^{29}$. We predicted most of the genes needed for these downstream steps (paaJGFH) in the genome, except the gene that code for hydrolytic cleavage of oxepin-CoA (paaZ). We assume this step might be catalyzed by other enzymes in strain Wilco ${ }^{29}$. The presence of the paa gene cluster responsible for phenylacetate degradation also suggests the organism's potential to metabolize similar compounds such as lignin-derived aromatic compounds as well environmental pollutants like styrene and ethylbenzene. The paa pathway is also utilized by Escherichia coli, Pseudomonas putida, other bacteria ${ }^{28,29,54}$ including halophiles such as Arhodomonas sp. strain Seminole ${ }^{48}$ and species of the genus Halomonas ${ }^{49}$.

Among the tested aromatic compounds, strain Wilcox did not degrade naphthalene or phenanthrene even after incubating for $>4$ weeks. The lack of degradation of naphthalene and phenanthrene is consistent with the lack of genes for the degradation of PAHs such as naphthalene 1,2-dioxygenase and PAH ring-hydroxylating dioxygenases (PAH-RHD), respectively, that catalyze the initial oxidation of naphthalene and $\mathrm{PAHs}^{55}$. Interestingly, a phylogenetically closely related organism isolated from a produced water treatment plant in Brazil, Modicisalibacter tunisiensis MOD 31.J, was found to degrade PAHs such as phenanthrene, pyrene, and benzopyrene ${ }^{22}$.

Among n-alkanes, strain Wilcox degraded n-decane and n-hexadecane as the sole sources of carbon in MSM supplemented with $2.5 \mathrm{M} \mathrm{NaCl}$, but no degradation of methane, hexane, $\mathrm{n}$-eicosane, and n-dotriacontane occurred under similar growth conditions (Table 3). Alkanes are a major component in crude oil and can be biodegraded in the environment by many microorganisms including some halophilic bacteria and archaea such as Alcanivorax sp., Streptomyces albiaxialis, Marinobacter hydrocarbonoclasticus, Haloarcula vallismortis EH4, and Haloferax sp. ${ }^{16,56-59}$. Alkanes are aerobically biodegraded by several pathways. In most cases, degradation is initiated by an alkane hydroxylase system $(\mathrm{AlkB})$ that oxidizes alkanes to corresponding alcohols. This enzyme system $(\mathrm{AlkB})$ consists of three components: the membrane-bound alkane hydroxylase coded by alkB that carries out the hydroxylation reaction and two soluble components, rubredoxin (coded by alk $G$ gene) and rubredoxin reductase (coded by alkT gene), that transfer electrons to the alkane hydroxylase. Generally, C10 to C16 n-alkanes are oxidized by the AlkB system ${ }^{60,61}$. The alcohols produced from n-alkanes undergo further oxidation to corresponding aldehydes and fatty acids by alcohol dehydrogenase and aldehyde dehydrogenase, respectively ${ }^{7,60-64}$. The fatty acids can then be metabolized by beta-oxidation pathway. Our genome analysis predicted the presence of rubredoxin- $\mathrm{NAD}(+)$ reductase only, and we did not find the other two components of the alkane hydroxylase system in the genome. However, laboratory studies showed rapid degradation of $\mathrm{n}$-decane and n-hexadecane, suggesting that enzymes other than canonical alkane hydroxylase may be involved the oxidation of alkanes. Strain Wilcox did not degrade methane, n-hexane, n-eicosane, or n-dotriacontane, consistent with the lack of specific genes for these shorter-chain and longer-chain $\mathrm{n}$-alkanes in the genome. The lack of methane metabolisms is consistent with the lack of the key gene methane monooxygenase ${ }^{65}$. Similarly, we did not find $\operatorname{alm} A$ or $\operatorname{lad} A$, which encode alkane degrading enzymes for longer-chain n-alkanes ${ }^{61,62}$. 
Conclusion. Although there have been recent studies showing the ability microorganisms to degrade petroleum compounds in various hypersaline environments, not much is known about similar organisms in PW. Hence, studies are needed that explore the ecology, physiology, diversity and hydrocarbon degradation potential of microorganisms native to PW. The isolation and characterization of strain Wilcox suggest that members of the genus Modicisalibacter could play an important role in the remediation of saline $\mathrm{PW}^{22,66}$. In the present work, we used genomic information to design and query strain Wilcox's ability to degrade both aliphatic and aromatic compounds in laboratory cultures. For many hydrocarbons, we predicted most of the essential genes needed for a complete metabolism under aerobic conditions. Laboratory studies showed that the strain can efficiently degrade both aliphatic and aromatic compounds at high salinity. Strain Wilcox also harbors genes for the detoxification mechanism of several heavy metals, consistent with presence of a variety of heavy metals in most PW. Furthermore, our bioaugmentation experiments revealed that strain Wilcox is capable of surviving and degrading hydrocarbons present in formation PW without the need for nutrient amendments, suggesting its application to clean-up of PW for beneficial uses.

\section{Materials and methods}

Chemicals and produced water. Benzene, toluene, ethylbenzene, xylenes, methane, hexane, hexadecane, phenanthrene, and naphthalene were purchased from Sigma-Aldrich, USA. Phenol, biphenyl, phenylacetate, benzoate, $n$-decane, n-eicosane, and n-dotriacontane were purchased from Fischer Scientific, USA. All other chemicals were of analytical grade and used without further purification. PW used in this study was obtained from the First Wilcox formation (36.03561 N, 97.04483 W), Payne County, OK. The composition of the PW is shown in Supplemental Table S1. The salinity of the PW was $4 \%(\mathrm{w} / \mathrm{v})$. Total alkalinity and pH were $146 \mathrm{mg} / \mathrm{L}$ and 7.42, respectively. Total Dissolved Solids was $146,600 \mathrm{mg} / \mathrm{L}$. The concentrations of magnesium and potassium were around $1,240 \mathrm{mg} / \mathrm{L}$ and $698 \mathrm{mg} / \mathrm{L}$, respectively. Low concentrations of several heavy metals were also present.

Enrichment and isolation of a hydrocarbon degrading bacteria from produced water. The enrichment was performed in $160-\mathrm{ml}$ serum bottles (Wheaton) containing $50 \mathrm{ml}$ of raw PW from First Wilcox formation, Payne County, OK, USA. Bottles were closed with 20-mm Teflon-lined septa and aluminum caps (The West Co). Bottles were injected with $2 \mu \mathrm{L}$ of each undiluted BTEX compounds and incubated in the dark in an inverted position. Air in the headspace ( $110 \mathrm{ml}$ headspace) served as the source of oxygen. Biodegradation of added BTEX was monitored using a gas chromatograph (GC) equipped with a flame ionization detector as described before ${ }^{40}$. Bottles were repeatedly fed BTEX with monthly transfer of $50 \%$ of the enrichment culture to a fresh MSM containing $2.5 \mathrm{M} \mathrm{NaCl}$ and BTEX $(25-35 \mu \mathrm{mol} /$ bottle). After 3-4 months of repeated feeding and transferring a $50 \%$ of the culture to fresh medium, a stable enrichment culture was obtained that degraded BTEX in 7 days as the sole carbon and energy sources.

For the isolation of pure culture, the enrichment was plated on to MSM agar plates containing $1 \mathrm{M} \mathrm{NaCl}$. The plates were incubated in a desiccator containing a glass vial with BTEX ( $2 \mathrm{ml}$ of undiluted BTEX mixture) until colonies appeared (1 week). Well isolated colonies were transferred to serum bottles containing $50 \mathrm{ml}$ of MSM supplemented with $1 \mathrm{M} \mathrm{NaCl}$ and 25-35 $\mu$ mole of each BTEX compound as the sources of carbon. Bottles were closed with Teflon-coated septa and aluminum caps. Headspace sample was withdrawn periodically and monitored for the added BTEX by GC. Bottles that showed rapid BTEX degradation were selected for further characterization and the purity of the isolates was tested by re-plating the culture.

16S rRNA -gene analysis of the isolate. An isolate that showed a good BTEX degradation capacity was selected for further study. Genomic DNA was extracted using the Ultra Clean soil DNA kit (Qiagen, Germantown, MD, USA). The isolate was identified by amplifying the $16 \mathrm{~S}$ rRNA -gene using the $27 \mathrm{~F}$ and $1492 \mathrm{R}$ primers as described before ${ }^{67}$. Amplified PCR product was cleaned using Exo SAP-IT and sequenced at the DNA core facility, Oklahoma State University, Stillwater, OK. The amplified 16S rRNA -gene sequences was analyzed using the National Center for Biotechnology Information (NCBI) database using BLASTN and taxonomically classified using the Silva v138 database ${ }^{68}$.

Mother inoculum. The isolate was maintained in 1-L bottles with $500 \mathrm{ml}$ of MSM supplemented with $2.5 \mathrm{M}$ $\mathrm{NaCl}$ and 25-35 $\mu$ mole of each BTEX compound as the sole source of carbon and energy. Bottles were closed with Teflon-coated septa and aluminum caps. Headspace was withdrawn periodically and monitored for consumption of the added BTEX. Roughly once every 4 weeks, $50 \%$ of the culture was replaced with fresh MSM containing $2.5 \mathrm{M} \mathrm{NaCl}$ and BTEX was injected. This culture served as the source of inoculum for all experiments presented in this article unless stated otherwise.

Genome sequencing, assembly, and annotation. Strain Wilcox was grown in MSM containing $1 \mathrm{M}$ $\mathrm{NaCl}$ and $5 \mathrm{mM}$ acetate as the sole source of carbon at $35^{\circ} \mathrm{C}$ for 1 week before DNA was extracted. Genomic DNA was extracted using the DNase PowerSoil kit (Qiagen, Germantown, MD, USA). Whole genome shotgun library preparation and sequencing were performed on Illumina HiSeq 4000 by Novogene Corporation (Beijing, China). The 5,747,630 raw 150 bp read pairs were randomly subsampled using Seqtk (https://github.com/lh3/ seqtk) to 1.7 million read pairs to achieve an approximate genome coverage of 100X. Reads were then trimmed using Trimmomatic v0.39 with a 4:30 sliding window and minimum length of $36 \mathrm{bp}$, yielding 1,317,369 read pairs and 169,285 and 53,458 forward and reverse unpaired reads, respectively ${ }^{69}$. All trimmed reads were assembled using SPAdes v3.13 with a minimum approximate coverage of $10 \mathrm{X}$ and minimum contig size of $500 \mathrm{bp}^{70}$. 
The resulting assembly consisted of 43 scaffolds with an N50 180,819, L50 of 7, and total assembly length of $3,584,069$ bp. 16S rRNA genes were detected in the assembly using barrnap v0.9 and taxonomy was investigated by submission to Silva database $v 138^{68,71}$. Assemblies were submitted to the IMG database ${ }^{72}$ for gene-calling, functional annotation, and to provide public access under genome ID number 2844586914. Un-annotated scaffolds were also deposited to GenBank under accession number WNXF00000000.1. Genes responsible for degradation of aromatic compounds were annotated by Integrated Microbial Genome-expert Review pipeline and the pathways of selective compounds were interpreted using KEGG orthology (KO), TIGRFAM (TIGR), and Clusters of Orthologous Genes (COG) assignments.

Hydrocarbon degradation experiments. Degradation of long-chain alkanes. Flasks (250 ml capacity) containing $100 \mathrm{ml}$ of MSM supplemented with $2.5 \mathrm{M} \mathrm{NaCl}$ were prepared and long-chain alkanes such as n-decane, $n$-hexadecane, $n$-eicosane or $n$-dotriacontane was added $(2-5 \mathrm{mM})$ as the sole carbon and energy source. Flasks were inoculated with $2 \mathrm{ml}$ (about $1.2 \times 10^{6} \mathrm{CFU}$ ) of strain Wilcox culture. Un-inoculated autoclaved flasks containing an $\mathrm{n}$-alkane were setup similarly and served control flasks. Also, inoculated flasks devoid of a substrate (an alkane) were prepared as controls. Flasks were closed with cotton plugs and incubated at $35{ }^{\circ} \mathrm{C}$ in the dark. Sample $(1 \mathrm{ml})$ was withdrawn periodically and a $10 \times$ serial dilution was performed and plated on to MSM agar plates containing $1 \mathrm{M} \mathrm{NaCl}$ and $5 \mathrm{mM}$ acetate as the carbon source. Plates were incubated at $35^{\circ} \mathrm{C}$ for 3 - 5 days and colony forming units (CFU) was determined. All treatments, here and below, were studied in triplicate microcosms.

Degradation of short-chain alkanes (methane and hexane). Degradation of methane was assessed in $160 \mathrm{ml}-$ capacity serum bottles filled with $49 \mathrm{ml}$ of MSM containing $2.5 \mathrm{M} \mathrm{NaCl}$. Bottles were inoculated with $1 \mathrm{ml}$ of strain Wilcox (about $6 \times 10^{5} \mathrm{CFU}$ ) and closed with rubber stoppers and aluminum crimps. Bottles were injected with $200 \mu \mathrm{l}$ of pure methane as the sole source carbon and air in the headspace served as the source of oxygen. Un-inoculated and autoclaved bottles containing methane were set up similarly as controls. Bottles were incubated upside-down at $35^{\circ} \mathrm{C}$ in the dark. Headspace sample was withdrawn periodically, and methane was quantified using a Hewlett Packard Agilent 6890 N GC (Agilent Technology) equipped with a TCD detector as described before ${ }^{41}$.

Biodegradation of hexane was assessed in $160 \mathrm{ml}$-capacity serum bottles filled with $49 \mathrm{ml}$ of MSM containing $2.5 \mathrm{M} \mathrm{NaCl}$. Bottles were amended with $5 \mathrm{mM}$ hexane as the sole carbon and energy source and sealed with rubber septa and aluminum caps. Bottles were inoculated with $1 \mathrm{ml}$ of strain Wilcox (about $6 \times 10^{5} \mathrm{CFU}$ ). Uninoculated autoclaved bottles containing hexane were set up similarly as controls. Also, bottles inoculated with strain Wilcox but lacking the substrate (hexane) were prepared similarly and served as controls. Bottles were incubated upside-down at $35^{\circ} \mathrm{C}$ in the dark. Culture sample $(1 \mathrm{ml})$ was withdrawn periodically and a $10 \times$ serial dilution was performed and plated on MSM agar plates containing $1 \mathrm{M} \mathrm{NaCl}$ and $5 \mathrm{mM}$ acetate as the carbon source. CFU was determined after 3-5 days of incubation.

Degradation of BTEX. Degradation of BTEX was tested in 160-ml-capacity serum bottles filled with $49 \mathrm{ml}$ of MSM containing $2.5 \mathrm{M} \mathrm{NaCl}$. Bottles were closed with Teflon-coated septa and aluminum caps and injected with $2 \mu \mathrm{l}$ of undiluted BTEX (each $25-35 \mu \mathrm{mol} /$ bottle) as the sole carbon and energy source. Bottles were inoculated with $1 \mathrm{ml}$ (roughly $6 \times 10^{5} \mathrm{CFU}$ ) of strain Wilcox. Un-inoculated and autoclaved bottles containing BTEX were set up similarly as controls. Bottles were incubated upside-down at $35^{\circ} \mathrm{C}$ in the dark. The headspace was withdrawn periodically, and degradation of BTEX was monitored using GC as mentioned above.

Salinity and BTEX degradation. The effect of salinity on BTEX degradation was determined in 160-ml serum bottles containing 48-ml of MSM supplemented with $0.016,0.5,1.0,2.0,3.0,4.0$ or $5.0 \mathrm{M} \mathrm{NaCl}$. Bottles were closed with Teflon-coated septa and aluminum caps. Bottles were injected with $2 \mu$ l of undiluted BTEX (each 25-35 $\mu$ mole) and inoculated with $2 \mathrm{ml}$ (roughly $2 \times 10^{6} \mathrm{CFU}$ ) of strain Wilcox. Un-inoculated and autoclaved bottles containing BTEX were set up similarly as controls. Bottles were incubated upside-down at $35^{\circ} \mathrm{C}$ in the dark. Headspace $(100 \mu \mathrm{L})$ was withdrawn periodically and degradation of the BTEX was measured using GC.

Degradation of benzoate, biphenyl, and phenylacetate. Flasks (250 ml capacity) containing $100 \mathrm{ml}$ MSM supplemented with $2.5 \mathrm{M} \mathrm{NaCl}$ and 1-2 mM benzoate, biphenyl, or phenylacetate as the sole source of carbon were set-up. Flasks were inoculated with $2 \mathrm{ml}$ of strain Wilcox $\left(5 \times 10^{4}\right.$ to $\left.1.2 \times 10^{6} \mathrm{CFU}\right)$ and incubated at $35^{\circ} \mathrm{C}$. Uninoculated and autoclaved flasks containing benzoate, biphenyl, or phenylacetate were prepared similarly and served as controls. Also, autoclaved flasks inoculated with strain Wilcox but lacking a substrate served as controls. Flasks were closed with cotton plugs and incubated at $35^{\circ} \mathrm{C}$ in the dark. To monitor benzoate degradation, culture $(1 \mathrm{ml})$ was withdrawn periodically and centrifuged at 9,391 $\times \mathrm{g}$ for $10 \mathrm{~min}$. The cell-free supernatant was appropriately diluted in nano pure water and benzoate concentration was monitored by measuring absorption at $223 \lambda$ using the Ultraspec 2000 UV/Visible spectrophotometer. To monitor the growth of strain Wilcox on biphenyl or phenylacetate as the sole carbon source, culture sample $(1 \mathrm{ml})$ was withdrawn periodically and a $10 \times$ serial dilution was performed and plated on MSM agar plates containing $1 \mathrm{M} \mathrm{NaCl}$ and $5 \mathrm{mM}$ acetate as the carbon source. Plates were incubated at $35^{\circ} \mathrm{C}$ for $3-5$ days and $\mathrm{CFU}$ was determined.

Degradation of phenol. Degradation of phenol was determined in 160-ml serum bottles filled with $49 \mathrm{ml}$ of MSM supplemented with $2.5 \mathrm{M} \mathrm{NaCl}$. Bottles were amended with $2 \mathrm{mM}$ phenol as the sole carbon and energy source and inoculated with $1 \mathrm{ml}$ of strain Wilcox culture (roughly $6 \times 10^{5} \mathrm{CFU}$ ). Bottles were closed with Teflon- 
coated septa and aluminum caps. Un-inoculated autoclaved flasks containing phenol were set up similarly as controls. Also, inoculated flasks devoid of phenol were set up similarly and served as controls. Bottles were incubated at $35^{\circ} \mathrm{C}$ in the dark. Culture sample $(1 \mathrm{ml})$ was withdrawn periodically and a $10 \times$ serial dilution was performed and plated on MSM agar plates containing $1 \mathrm{M} \mathrm{NaCl}$ and $5 \mathrm{mM}$ acetate as the carbon source. Plates were incubated at $35^{\circ} \mathrm{C}$ for $3-5$ days and CFU was determined.

Bioaugmentation potential of strain Wilcox. Serum bottles (160-ml capacity) were filled with 48-ml of formation PW from Payne County (nothing other than BTEX compounds were added). Bottles were closed with Teflon-coated septa and aluminum caps and sterilized by autoclaving. Bottles were amended with 100$200 \mu \mathrm{mol}$ of each BTEX compound combined. Also, bottles were prepared similarly and amended with 100-200 $\mu$ moles of $\mathrm{B}, \mathrm{T}, \mathrm{E}$ or $\mathrm{X}$ (as individual compounds). All bottles were inoculated with $2 \mathrm{ml}$ of strain Wilcox culture (roughly $2 \times 10^{6} \mathrm{CFU}$ ). Autoclaved un-inoculated bottles amended with 100-200 $\mu$ mol of each B, T, E, and/or X compound (s) were prepared similarly and served as controls. $100 \mu \mathrm{L}$ headspace was withdrawn periodically to determine degradation of the BTEX compounds using GC. The composition of the formation PW can be found in Supplemental Table S1.

\section{Data availability}

Assemblies were submitted to the IMG database for gene-calling, functional annotation, and to provide public access under genome ID number 2844586914. Un-annotated scaffolds were also deposited to GenBank under accession number WNXF00000000.1.

Received: 18 December 2020; Accepted: 5 March 2021

Published online: 25 March 2021

\section{References}

1. Pichtel, J. Oil and gas production wastewater: soil contamination and pollution prevention. Appl. Environ. Soil. Sci. Article ID 2707989; https://doi.org/10.1155/2016/2707989 (2016).

2. Kharaka, Y. K. \& Otton, J. K. Environmental impacts of petroleum production: initial results from the Osage-Skiatook petroleum environmental research sites, Osage County, Oklahoma. Water-Resources Investigations Report 03-4260; https://pubs.usgs.gov/ wri/wri03-4260 (2003).

3. Abbasian, F., Lockington, R., Megharaj, M. \& Naidu, R. A review on the genetics of aliphatic and aromatic hydrocarbon degradation. Appl. Biochem. Biotechnol. 178, 224-250 (2016).

4. Ali, N., Dashti, N., Khanafer, M., Al-Awadhi, H. \& Radwan, S. Bioremediation of soils saturated with spilled crude oil. Sci. Rep. 10, $1116(2020)$.

5. Brzeszcz, J. \& Kaszycki, P. Aerobic bacteria degrading both n-alkanes and aromatic hydrocarbons: an undervalued strategy for metabolic diversity and flexibility. Biodegradation 29, 359-407 (2018).

6. Das, N. \& Chandran, P. Microbial degradation of petroleum hydrocarbon contaminants: an overview. Biotechnol. Res. Int. 2011, Article ID 941810; https://doi.org/10.4061/2011/941810 (2011).

7. Harayama, S., Kishira, H., Kasai, Y. \& Shutsubo, K. Petroleum biodegradation in marine environments. J. Mol. Microbiol. Biotechnol. 1, 63-70 (1999).

8. Hong, Y.-H. et al. Genome sequencing reveals the potential of Achromobacter sp. HZ01 for bioremediation. Front. Microbiol. 8, Article 1507; https://doi.org/10.3389/fmicb. 2017.01507 (2017).

9. Pérez-Pantoja, D., González, B., \& Pieper, D. H. (2019). Aerobic degradation of aromatic hydrocarbons. In Handbook of hydrocarbon and lipid microbiology. (ed. Rojo F.), 157-200 (Springer Nature Switzerland).

10. Seo, J.-S., Keum, Y.-S. \& Li, Q. X. Bacterial degradation of aromatic compounds. Int. J. Env. Res. Pub. Health. 6, 278-309 (2009).

11. Veil, John. US produced water volumes and management practices in 2012. Groundwater Protection Council (2015).

12. Scanlon, B. R. et al. Can we beneficially reuse produced water from oil and gas extraction in the U.S.? Sci. Total Environ. 717, 137085; https://doi.org/10.1016/j.scitotenv.2020.137085 (2020).

13. Akob, D. M. et al. Wastewater disposal from unconventional oil and gas development degrades stream quality at a West Virginia injection facility. Environ. Sci. Technol. 50, 5517-5525 (2016).

14. Ellsworth, W. L. Injection-induced earthquakes. Science 341, 6142 (2013).

15. Edbeib, M. F., Wahab, R. A. \& Huyop, F. Halophiles: biology, adaptation, and their role in decontamination of hypersaline environments. World J. Microb. Biot. 32, Article 135; https://doi.org/10.1007/s11274-016-2081-9 (2016).

16. Fathepure, B. Z. Recent studies in microbial degradation of petroleum hydrocarbons in hypersaline environments. Front. Microbiol. 5, Article 173; https://doi.org/10.3389/fmicb.2014.00173 (2014).

17. Le Borgne, S., Paniagua, D. \& Vazquez-Duhalt, R. Biodegradation of organic pollutants by halophilic bacteria and archaea. J. Mol. Microbiol. Biotechnol. 15, 74-92 (2008).

18. Martins, L. F. \& Peixoto, R. S. Biodegradation of petroleum hydrocarbons in hypersaline environments. Braz. J. Microbiol. 43, 865-872 (2012).

19. Oren, A. Aerobic hydrocarbon-degrading Archaea in Taxonomy, Genomics and Ecophysiology of Hydrocarbon Degrading Microbes, Handbook of Hydrocarbon and Lipid Microbiology (ed. McGenity T. J.), 41-51 (Springer Nature Switzerland, 2019).

20. Sorokin, D. Y., Janssen, A. J. H. \& Muyzer, G. Biodegradation potential of halo(alkali)philic prokaryotes. Crit. Rev. Environ. Sci. Technol. 42, 811-856 (2012).

21. Gam, Z. B. A. et al. Modicisalibacter tunisiensis gen. nov., sp. nov., an aerobic, moderately halophilic bacterium isolated from an oilfield-water injection sample, and emended description of the family Halomonadaceae Franzmann et al. 1989 emend Dobson and Franzmann 1996 emend. Ntougias et al. 2007. Int. J. Syst. Evol. Microbiol. 57, 2307-2313 (2007).

22. Gomes, M. B. et al. Exploring the potential of halophilic bacteria from oil terminal environments for biosurfactant production and hydrocarbon degradation under high-salinity conditions. Int. Biodeter. Biodegr. 126, 231-242 (2018).

23. Pruesse, E., Peplies, J. \& Glöckner, F. O. SINA: accurate high-throughput multiple sequence alignment of ribosomal RNA genes. Bioinformatics 28, 1823-1829 (2012).

24. Gibson, D. T. \& Parales, R. E. Aromatic hydrocarbon dioxygenases in environmental biotechnology. Curr. Opin. Biotechnol. 3, 236-243 (2000).

25. Reineke, W. \& Knackmuss, H.-J. Chemical structure and biodegradability of halogenated aromatic compounds substituent effects on 1,2-dioxygenation of benzoic acid. Biochim et Biophys Acta (BBA)-General Subjects 542, 412-423 (1978).

26. Yamamoto, S., Katagiri, M., Maeno, H. \& Hayaishi, O. Salicylate hydroxylase, a monooxygenase requiring flavin adenine dinucleotide I. Purification and general properties. J. Biol. Chem, 240, 3408-3413 (1965). 
27. Ismail, W. \& Gescher, J. Epoxy coenzyme A thioester pathways for degradation of aromatic compounds. Appl. Environ. Microbiol. 78, 5043-5051 (2012).

28. Luengo, J. M., García, J. L. \& Olivera, E. R. The phenylacetyl-CoA catabolon: a complex catabolic unit with broad biotechnological applications. Mol. Microbiol. 39, 1434-1442 (2001).

29. Teufel, R. et al. Studies on the mechanism of ring hydrolysis in phenylacetate degradation; a metabolic branching point. J. Biol. Chem. 286, 11021-11034 (2011).

30. Peng, R.-H. et al. Microbial biodegradation of polyaromatic hydrocarbons. FEMS Microbiol. Rev. 32, 927-955 (2008).

31. Harwood, C. S. \& Parales, R. E. The beta-ketoadipate pathway and the biology of self-identity. Annu. Rev. Microbiol. 50, 553-590 (1996).

32. Nies, D. H. Efflux-mediated heavy metal resistance in prokaryotes. FEMS Microbiol. Rev. 27, 313-339 (2003).

33. Fakhru'l-Razi, A. et al. Review of technologies for oil and gas produced water treatment. J. Hazard. Mater. 170, 530-551 (2009).

34. Palmgren, M. G. \& Axelsen, K. B. Evolution of P-type ATPases. Biochim. Biophys. Acta 1365, 37-45 (1998).

35. Palmgren, M. G. \& Nissen, P. P-type ATPases. Ann. Rev. Biophys. 40, 243-266 (2011).

36. Branco, R., Chung, A.-P. \& Morais, P. V. Sequencing and expression of two arsenic resistance operons with different functions in the highly arsenic-resistant strain Ochrobactrum tritici SCII24T. BMC Microbiol. 8, 95 (2008).

37. Wu, S. et al. Signature arsenic detoxification pathways. mBio 9, e00515-e518 (2018).

38. Boyd, E. S. \& Barkay, T. The mercury resistance operon: from an origin in a geothermal environment to an efficient detoxification machine. Front. Microbiol. 3, 349 (2012).

39. Voica, D.M., Bartha, L., Banciu, H.L. \& Oren, A. Heavy metal resistance in halophilic Bacteria and Archaea. FEMS Microbiol Lett. 363, (2016).

40. Nicholson, C. A. \& Fathepure, B. Z. Biodegradation of benzene by halophilic and halotolerant bacteria under aerobic conditions. Appl. Environ. Microbiol. 70, 1222-1225 (2004).

41. Liu, K. et al. Mixed culture syngas fermentation and conversion of carboxylic acids into alcohols. Bioresour. Technol. 152, 337-346 (2014).

42. Dalvi, S., Youssef, N. H. \& Fathepure, B. Z. Microbial community structure analysis of a benzoate-degrading halophilic archaeal enrichment. Extremophiles 20, 311-321 (2016).

43. Jepsen, K. L., Bram, M. V., Pedersen, S. \& Yang, Z. Membrane fouling for produced water treatment: a review study from a process control perspective. Water 10, 847 (2018).

44. Abou Khalil C., Prince V. L., Prince, R. C., Greer, C. W., Lee, K., Zhang, B., \& Boufadel, M. C. Occurrence and biodegradation of hydrocarbons at high salinities. Sci. Total Environ. In Press Article 143165; doi.org/https://doi.org/10.1016/j.scitotenv.2020.143165 (2020).

45. Benka-Coker, M. O. \& Ekundayo, J. A. Effects of heavy metals on growth of species of Micrococcus and Pseudomonas in a crude oil/mineral salts medium. Bioresour. Technol. 3, 241-245 (1998).

46. Iwegbue, C. M. Assessment of heavy metal speciation in soils impacted with crude oil in the Niger Delta Nigeria. Chem. Spec. Bioavailab. 23, 7-15 (2011).

47. Srivastava, P. \& Kowshik, M. Mechanisms of metal resistance and homeostasis in haloarchaea. Archaea 2013, Article ID 732864; https://doi.org/10.1155/2013/732864 (2013).

48. Dalvi, Sonal, et al. Arhodomonas sp. strain seminole and its genetic potential to degrade aromatic compounds under high-salinity conditions. Applied and Environ Microbiol 80, 6664-6676 (2014)

49. García, M. T., Ventosa, A. \& Mellado. E. Catabolic versatility of aromatic compound-degrading halophilic bacteria. FEMS Microbiol. Ecol. 54, 97-109 (2005).

50. Cafaro, V. et al. Phenol hydroxylase and toluene/o-xylene monooxygenase from Pseudomonas stutzeri OX1: interplay between two enzymes. Appl. Environ. Microbiol. 70, 2211-2219 (2004).

51. Dalvi, S., Azetsu, S., Patrauchan, M. A., Aktas, D. F. \& Fathepure, B. Z. Proteogenomic elucidation of the initial steps in the benzene degradation pathway of a novel halophile, Arhodomonas sp. strain Rozel, isolated from a hypersaline environment. Appl. Environ. Microbiol. 78, 7309-7316 (2012).

52. Reiner, A. M. Metabolism of aromatic compounds in bacteria; purification and properties of the catechol-forming enzyme, 3,5-cyclohexadiene-1,2-diol-1-carboxylic acid (NAD+) oxidoreductase (decarboxylating). J. Biol. Chem. 247, 4960-4965 (1972).

53. Garrido-Sanz, D., Manzano, J., Martín, M., Redondo-Nieto, M. \& Rivilla, R. Metagenomic analysis of a biphenyl-degrading soil bacterial consortium reveals the metabolic roles of specific populations. Front. Microbiol. 9, Article 232; https://doi.org/10.3389/ fmicb.2018.00232 (2018).

54. Chen, Xi, et al. Phenylacetic acid catabolism and its transcriptional regulation in Corynebacterium glutamicum. Appl. Environ. Microbiol. 78, 5796-5804 (2012).

55. Liang, C., Huang, Y. \& Wang, H. pahE, a functional marker gene for polycyclic aromatic hydrocarbon-degrading bacteria. Appl. Environ. Microbiol. 85, e02399-18; https://doi.org/10.1128/AEM.02399-18 (2019).

56. Al-Mailem, D. M., Sorkhoh, N. A., Al-Awadhi, H., Eliyas, M. \& Radwan, S. S. Biodegradation of crude oil and pure hydrocarbons by extreme halophilic archaea from hypersaline coasts of the Arabian Gulf. Extremophiles 14, 321-328 (2010).

57. Bertrand, J. C., Almallah, M., Acquaviva, M. \& Mille, G. Biodegradation of hydrocarbons by an extremely halophilic archaebacterium. Lett. Appl. Microbiol. 11, 260-263 (1990).

58. Gauthier, M. J. et al. Marinobacter hydrocarbonoclasticus gen. nov., sp. nov., a new, extremely halotolerant, hydrocarbon-degrading marine bacterium. Int. J. Syst. Evol. Micr. 42, 568-576 (1992).

59. Kuznetsov, V. D., Zaitseva, T. A., Vakulenko, L. V. \& Filippova S. N. Streptomyces albiaxialis sp. nov.-a new petroleum hydrocarbondegrading species of thermo- and halotolerant Streptomyces. Microbiol. 61, 62-67 (1992).

60. Rojo, F. Degradation of alkanes by bacteria. Environ. Microbiol. 11, 2477-2490 (2009).

61. Nie, Y. et al. Diverse alkane hydroxylase genes in microorganisms and environments. Sci. Rep. 4, 4968 (2014).

62. Ji, Y., Mao, G., Wang, Y. \& Bartlam, M. Structural insights into diversity and $n$-alkane biodegradation mechanisms of alkane hydroxylases. Front. Microbiol. 4, Article 58 (2013).

63. Tani, A., Ishige, T., Sakai, Y. \& Kato, N. Gene structures and regulation of the al3ane hydroxylase complex in Acinetobacter sp. strain M-1. J. Bacteriol. 183, 1819-1823 (2001).

64. van Beilen, J. B., Wubbolts, M. G. \& Witholt, B. Genetics of alkane oxidation by Pseudomonas oleovorans. Biodegradation 5, 161-174 (1994).

65. Iguchi, H., Yurimoto, H. \& Sakai, Y. Soluble and particulate methane monooxygenase gene clusters of the type I methanotroph Methylovulum miyakonense HT12. FEMS Microbial. Letts. 312, 71-76 (2010).

66. Bonfá, M. R. L., Grossman, M. J., Piubeli, F., Mellado, E. \& Durrant, L. R. Phenol degradation by halophilic bacteria isolated from hypersaline environments. Biodegradation 24, 699-709 (2013).

67. Spear, J. R., Walker, J. J., McCollom, T. M. \& Pace, N. R. Hydrogen and bioenergetics in the Yellowstone geothermal ecosystem. Proc. Natl. Acad. Sci. USA 102, 2555-2560 (2005).

68. Quast, C. et al. The SILVA ribosomal RNA gene database project: improved data processing and web-based tools. Nucleic Acids Res. 41(D1), D590-D596. https://doi.org/10.1093/nar/gks1219 (2012).

69. Bolger, A. M., Lohse, M. \& Usadel, B. Trimmomatic: a flexible trimmer for Illumina sequence data. Bioinformatics 30, 2114-2120 (2014). 
70. Bankevich, A. et al. SPAdes: A new genome assembly algorithm and its applications to single-cell sequencing. J. Comput. Biol. 19, $455-477$ (2012).

71. Seeman, T. Tseemann/barrnap: Bacterial ribosomal RNA predictor. Retrieved November 1, 2019 from https://github.com/tseem ann/barrnap (2018).

72. Chen, I.-M. A. et al. IMG/M v.5.0: an integrated data management and comparative analysis system for microbial genomes and microbiomes. Nucleic Acids Res. 47 (D1), D666-D677 (2019).

\section{Acknowledgements}

This work was supported in part by the NSF-EPSCoR grant (OIA-1946093) and the College of Arts and Sciences, OSU (Teaching Assistant support to Mr. William Marsh). The authors thank Mr. Christian Wilson and Ms. Teresa Mccarrell for assisting with microcosm studies. We are grateful to Dr. David Leavitt for providing us with the First Wilcox produced water used in this study.

\section{Author contributions}

W.S.M, and B.W.H. Carried out the experiment, collected data, prepared figures and tables. B.Z.F. M.J.K, R.W.M, WSM. wrote the manuscript. R.W.M. Analyzed the bioinformatics data. B.Z.F. Conceived the experiments, managed the project and obtained the funding. All authors reviewed the manuscript.

\section{Competing interests}

The authors declare no competing interests.

\section{Additional information}

Supplementary Information The online version contains supplementary material available at https://doi.org/ 10.1038/s41598-021-86196-0.

Correspondence and requests for materials should be addressed to B.Z.F.

Reprints and permissions information is available at www.nature.com/reprints.

Publisher's note Springer Nature remains neutral with regard to jurisdictional claims in published maps and institutional affiliations.

(c) (1) Open Access This article is licensed under a Creative Commons Attribution 4.0 International License, which permits use, sharing, adaptation, distribution and reproduction in any medium or format, as long as you give appropriate credit to the original author(s) and the source, provide a link to the Creative Commons licence, and indicate if changes were made. The images or other third party material in this article are included in the article's Creative Commons licence, unless indicated otherwise in a credit line to the material. If material is not included in the article's Creative Commons licence and your intended use is not permitted by statutory regulation or exceeds the permitted use, you will need to obtain permission directly from the copyright holder. To view a copy of this licence, visit http://creativecommons.org/licenses/by/4.0/.

(C) The Author(s) 2021 